\title{
REMOTE-HANDLED TRANSURANIC CONTENT CODES
}

(RH-TRUCON) 
TABLE 1

\section{CROSS CORRELATION TABLE}

\begin{tabular}{|c|c|c|c|}
\hline SHIPPING SITE & GENERATING SITE & $\underline{\text { IDC }}$ & CONTENT CODE \\
\hline BCL & BCL & N/A & BC 312A \\
\hline BCL & BCL & N/A & BC 314A \\
\hline BCL & BCL & N/A & BC 321A \\
\hline BCL & BCL & N/A & BC 321B \\
\hline BCL & BCL & N/A & BC 322A \\
\hline ETEC & ETEC & 253 & ET 325A \\
\hline ETEC & ETEC & N/A & ET 326A \\
\hline ETEC & ETEC & N/A & ET 326B \\
\hline LANL & LANL & 007 & LA 325A \\
\hline LANL & LANL & 007 & LA 325B \\
\hline LANL & LANL & 007 & LA 325C \\
\hline ORNL & ORNL & N/A & OR 311A \\
\hline ORNL & ORNL & N/A & OR 325A \\
\hline
\end{tabular}


Each content code uniquely identifies the generated waste and provides a system for tracking the process and packaging history. Each content code begins with a two-letter site abbreviation that designates the physical location of the RH-TRU waste. The site-specific letter designations for each of the DOE sites are provided in Table 2. All TRU waste generating/storage sites are included in Table 2 for completeness. Not all of the sites listed in Table 2 have generated/stored RH-TRU waste.

Following the site abbreviation is a three-digit numerical code that categorizes the RH-TRU waste materials. These three-digit codes are based on a system used to characterize contact-handled (CH)-TRU waste. For RH-TRU waste, the first number of the content code is either a "3" or "4," which provides a distinction between newly generated and retrievably stored waste. For example, a content code " $3 X X$ " is newly generated RH-TRU waste, and a content code " $4 \mathrm{XX}$ " is retrievably stored RH-TRU waste. Newly generated waste is defined as waste generated after the WIPP waste certification program had been implemented at each site. Retrievably stored waste is that which was generated before the implementation of the certification program. The CH-TRU waste system uses "1" and "2" as the first number of the three-digit code to segregate the waste in a similar manner. The last two digits of the three digit code are used to categorize the waste into content codes based on its physical and chemical characteristics. Tables 3 and 4 list potential content codes and a short description of each content code for newly generated waste and retrievably stored waste, respectively. All of the content codes in Tables 3 and 4 may not be used but are included for completeness. These content codes can be grouped into four basic waste types that encompass all of the RH-TRU waste in the system. The waste types are indicated along with the corresponding content codes in Tables 3 and 4. The waste types are:

$$
\begin{aligned}
& \text { I } \quad \text { - Solidified Inorganics } \\
& \text { II }- \text { Solid Inorganics } \\
& \text { III }- \text { Solid Organics } \\
& \text { IV }- \text { Solidified Organics }
\end{aligned}
$$

At the end of each content code is an alpha code. This alpha code is used to accommodate different packaging configurations that may exist within a content code. These alpha codes identify the combination of external packaging (e.g., RH-TRU waste canister) and internal packaging configuration used (e.g., use of plastic buckets and bags, metal cans, and overpacking 55-gallon drums in the RH-TRU waste canister). Identification by packaging configuration is necessary to characterize the release rate of any generated gases from the waste. Because packaging techniques are unique to a generator/storage site, there is no standard definition for the alpha codes. The alpha codes are simply indicative of different packaging configurations within a content code. This content code-specific information is provided in this document. 


\section{TABLE 2}

\section{WASTE SHIPPER SITE IDENTIFICATION CODES}

\section{SITE NAME}

Argonne National Laboratory - East (ANL-E)

Argonne National Laboratory - West (ANL-W)

Battelle Columbus Laboratory (BCL)

Battelle - Pacific Northwest Laboratory (PNL)

Bettis Atomic Power Laboratory (BET)

Energy Technology Engineering Center (ETEC)

Idaho National Engineering and Environmental Laboratory (INEEL)

Los Alamos National Laboratory (LANL)

Lawrence Livermore National Laboratory (LLNL)

Mound

Nevada Test Site (NTS)

Oak Ridge National Laboratory (ORNL)

Rocky Flats Environmental Technology Site (RFETS)

Richland Hanford (RH)

Savannah River Site (SRS)
SITE IDENTIFICATION CODE

$\mathrm{AE}$

AW

BC

BP

$\mathrm{BE}$

ET

ID

LA

LL

MD

NT

OR

RF

$\mathrm{RH}$

SR 
Each of the content codes for RH-TRU materials has a 5\% (by volume) limit on the hydrogen concentration that can be present in any confinement layer of a waste container. The sites have two options to comply with these limits:

Option 1: Convert the 5\% restriction on hydrogen concentration to a limit on the allowable hydrogen generation rate for each content code (as described in Appendix 3.6.9 of the 72-B Cask SARP). If it can be shown for a given waste container that this limit can be met, the hydrogen concentration will remain at or below 5\% under transportation conditions. Attachment 2 of Appendix 1.3.7 of the 72-B Cask SARP provides procedures to be used for the determination of hydrogen generation rates. Maximum allowable hydrogen generation rates for the RH-TRU content codes are summarized in Tables 5 and 6.

Option 2: Convert the 5\% restriction on hydrogen concentration to a limit on the allowable decay heat per waste container (as described in Appendix 3.6.9 of the 72-B Cask SARP). Since radiolysis of the waste materials is the primary mechanism by which hydrogen can be generated, the $5 \%$ limit on hydrogen concentration imposes a limit on the allowable decay heat per waste container. If it can be shown for a given waste container that this limit can be met, the hydrogen concentration will remain at or below 5\% under transportation conditions. Procedures for determining the decay heat values for waste containers are described in Section 10.0 of Appendix 1.3.7 of the 72-B Cask SARP. Maximum allowable decay heat limits for the RH-TRU content codes are also summarized in Tables 5 and 6.

The content codes defined in this document are fully characterized with respect to the following parameters:

- Content Description

- $\quad$ Storage Site (if applicable)

- Generating Site

- Waste Description

- Generating Source(s)

- Waste Form

- Waste Packaging

- Methods for Isotopic Determination

- Free Liquids

- Explosives/Compressed Gases

- Pyrophorics

- Corrosives

- Chemical Compatibility

- Venting and Aspiration (if applicable)

- Additional Criteria

- Option 1 -Maximum Allowable Hydrogen Generation Rate

- Option 2 - Maximum Allowable Decay Heat Limit

- Correlation Table for Content Codes 


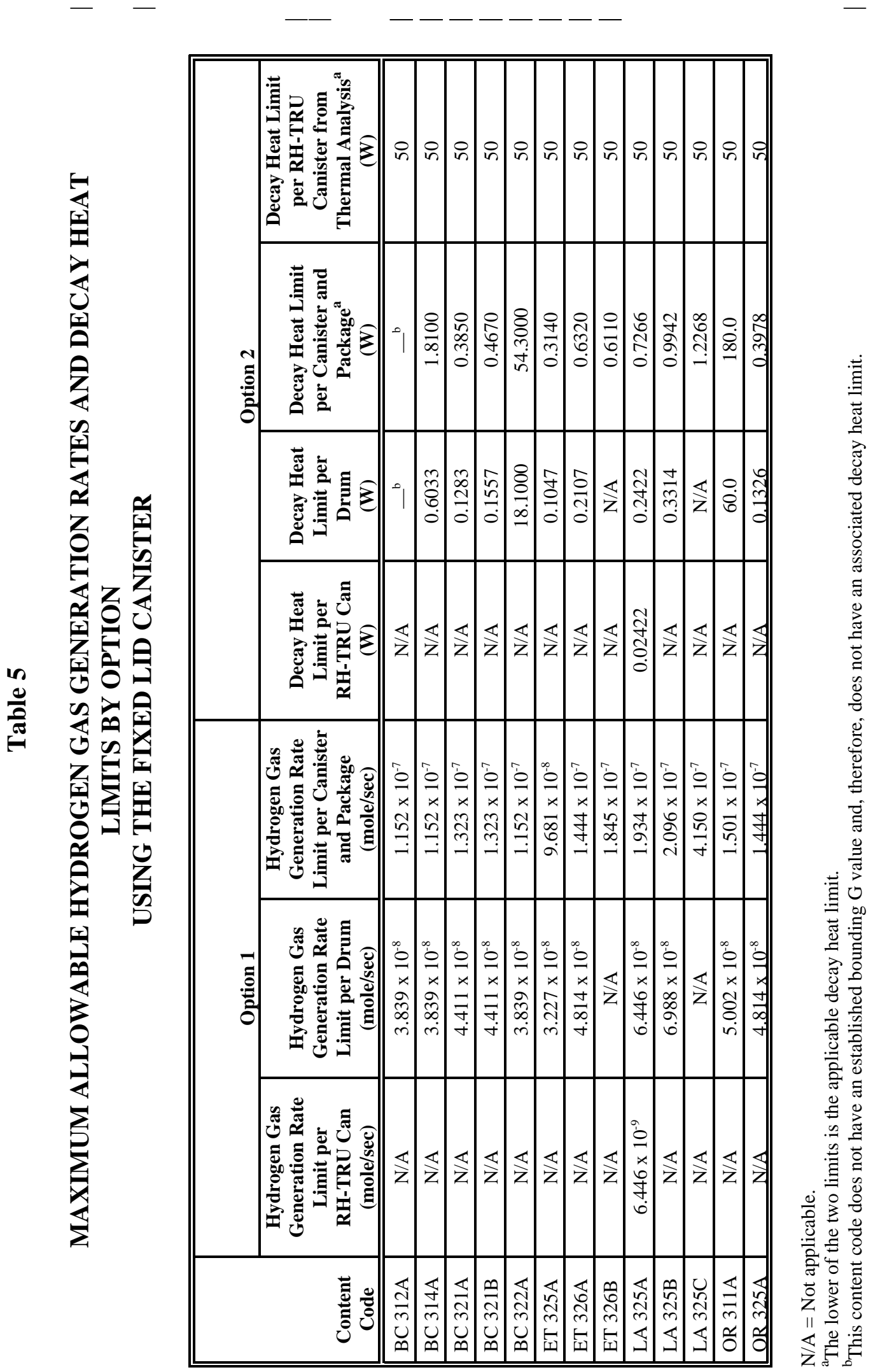




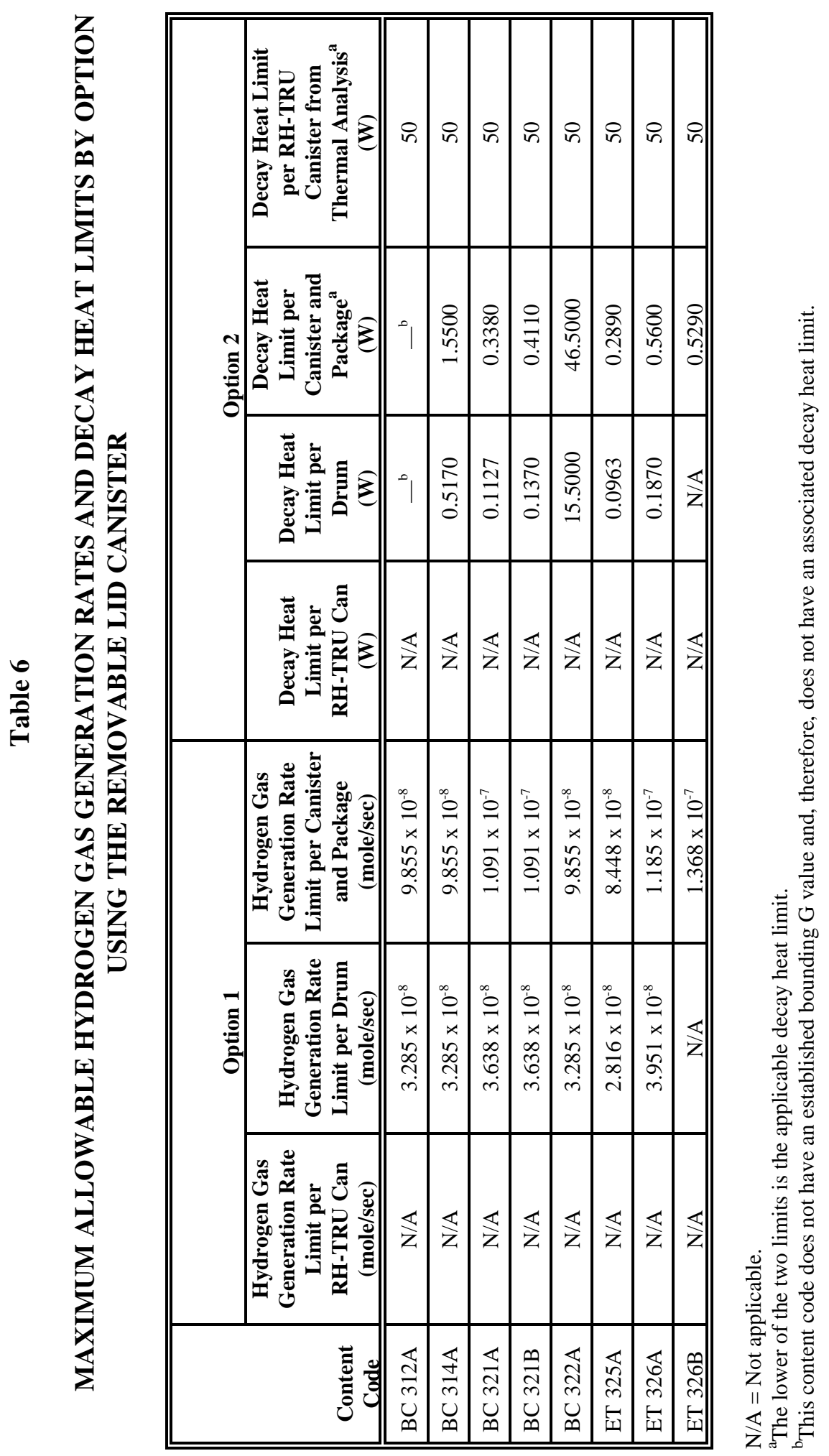


CONTENT CODE: BC 312A

CONTENT DESCRIPTION: Solidified Organic Waste

GENERATING SITE: Battelle Columbus Laboratories (BCL)

STORAGE SITE: BCL

WASTE DESCRIPTION: This waste consists of solidified organic and inorganic wastes.

GENERATING SOURCE(S): This waste is generated during research and development activities conducted in Building $\mathrm{JN}-1$.

WASTE FORM: The waste consists primarily of inorganic and organic liquids that have been solidified using Floor Dry. The inorganic liquids include acids and acid solutions and elemental mercury. The organic liquids include hydraulic oil, waste water, sludge of sand and mixed fission products (dust, small fragments); small items such as tools; and nonhalogenated organic liquids such as glycols, oils, and alcohols.

WASTE PACKAGING: The waste will be placed directly into a 55-gallon drum with no layers of confinement. The drum is lined with a steel liner. Three drums will then be placed into the RH-TRU waste canister.

METHOD(S) FOR ISOTOPIC DETERMINATION: The isotopic information required to demonstrate compliance with the limits on fissile content, decay heat, and curie content will be determined based on the waste generation source and configuration, which establish the initial radionuclide compositions based on location and initial use. A combination of assaying samples and modeling of the isotopic generation processes results in the establishment of a mixture that characterizes the waste in the content code and the majority of waste at the Battelle Columbus Laboratories Decommissioning Project (BCLDP). Using shipping package modeling, dose rate and weight measurements based on the mixture then allow the BCLDP to determine the isotopic inventory. As required, additional radioassays (e.g., confirming gamma spectrometry) will be performed. 
FREE LIQUIDS: Liquid waste, except for residual amounts in well-drained containers, is prohibited in the drums. The total volume of residual liquid in a payload container shall be less than 1 volume percent of the payload container. Waste packaging procedures ensure that free liquids are less than 1 volume percent of the payload container. Absorbents such as Radsorb or diatomaceous earth (e.g., Floor Dry) will be added to any waste matrix that has the potential to dewater after packaging.

EXPLOSIVES/COMPRESSED GASES: Explosives and compressed gases in the payload containers are prohibited by waste packaging procedures. If present, pressurized cans shall be punctured and emptied prior to packaging.

PYROPHORICS: Nonradioactive pyrophorics in the payload containers are prohibited by waste packaging procedures. Waste packaging procedures shall ensure that all pyrophoric radioactive materials are present only in small residual amounts (less than 1 weight percent) in payload containers.

CORROSIVES: Corrosives are prohibited in the payload container. Acids and bases that are potentially corrosive shall be neutralized and rendered noncorrosive prior to being a part of the waste. The physical form of the waste and the waste generating procedures ensure that the waste is in a nonreactive form.

CHEMICAL COMPATIBILITY: A chemical compatibility study has been performed on this content code, and all waste is chemically compatible for materials in greater than trace ( $>1 \%$ by weight) quantities. The chemicals found in this content code are identified in the attached list and are restricted to the allowable chemical lists determined by the methodology found in the RH-TRU 72-B Cask Safety Analysis Report (SAR).

ADDITIONAL CRITERIA: Each drum is fitted with a minimum of one filter vent with a minimum hydrogen diffusivity of 3.7E-06 mole/second/mole fraction. The steel liner is fitted with a filter with a minimum hydrogen diffusivity of 3.7E-06 mole/second/mole fraction.

MAXIMUM ALLOWABLE HYDROGEN GENERATION RATES - OPTION 1: The maximum allowable hydrogen generation rate limit is 3.8391E-08 moles per second per drum and 1.1517E-07 moles per second per RH-TRU waste canister with a fixed lid. The maximum allowable hydrogen generation rate limit is 3.2850E-08 moles per second per drum and 9.8550E-08 moles per second per RH-TRU waste canister with a removable lid. 
MAXIMUM ALLOWABLE DECAY HEAT LIMITS - OPTION 2: There is no decay heat limit for this content code as no $\mathrm{G}$ values have been established. Waste cannot be transported under Option 2.

CORRELATION TABLE: N/A 


\title{
BATTELLE COLUMBUS LABORATORIES CONTENT CODE BC 312A SOLIDIFIED ORGANIC WASTE
}

\author{
MATERIALS AND CHEMICALS $>1 \%$
}

DIATOMACEOUS EARTH (Floor Dry)

ACIDS AND ACID SOLUTIONS

MERCURY

HYDRAULIC OIL, GLYCOLS, OILS, AND ALCOHOLS

SAND

RADSORB

VERMICULITE

AQUA-SET/PETRO-SET

\section{MATERIALS AND CHEMICALS $<1 \%$}

METALS (including stainless steel, aluminum, iron, copper, lead, beryllium, and zirconium) 
CONTENT CODE: BC 314A

CONTENT DESCRIPTION: Cemented Inorganic Process Solids

GENERATING SITE: Battelle Columbus Laboratories (BCL)

STORAGE SITE: BCL

WASTE DESCRIPTION: This waste consists of slugs produced from dissolving fuel specimens in an acid solution that was then diluted several times and mixed with cement and allowed to solidify in foam cups.

GENERATING SOURCE(S): This waste is generated during repackaging of the waste materials generated from research and development activities conducted in Building JN-1.

WASTE FORM: The waste consists of slugs produced from dissolving fuel specimens in an acid solution, which was then diluted several times and mixed with cement and allowed to solidify in foam cups. The slugs will contain limited amounts of radionuclides from fuel because of this dilution. The waste matrix will also include Floor Dry added during repackaging to absorb any water from condensation or dewatering.

WASTE PACKAGING: The waste will be placed directly into a 55-gallon drum with no layers of confinement. The drum is lined with a steel liner. Three drums will then be placed into the RH-TRU waste canister.

METHOD(S) FOR ISOTOPIC DETERMINATION: The isotopic information required to demonstrate compliance with the limits on fissile content, decay heat, and curie content will be determined based on the waste generation source and configuration, which establish the initial radionuclide compositions based on location and initial use. A combination of assaying samples and modeling of the isotopic generation process used in the establishment of a mixture that characterizes the waste in the content code and the majority of waste at the Battelle Columbus Laboratories Decommissioning Project (BCLDP). Using shipping package modeling, dose rate and weight measurements based on the mixture then allow the BCLDP to determine the isotopic inventory. As required, additional radioassays (e.g., confirming gamma spectroscopy) will be performed. 
FREE LIQUIDS: Liquid waste, except for residual amounts in well-drained containers, is prohibited in the drums. The total volume of residual liquid in a payload container shall be less than 1 volume percent of the payload container. Waste packaging procedures ensure that free liquids are less than 1 volume percent of the payload container. Absorbents such as diatomaceous earth (e.g., Floor Dry) will be added to any waste matrix that has the potential to dewater after packaging.

EXPLOSIVES/COMPRESSED GASES: Explosives and compressed gases in the payload containers are prohibited by waste packaging procedures. If present, pressurized cans shall be punctured and emptied prior to packaging.

PYROPHORICS: Nonradioactive pyrophorics in the payload containers are prohibited by waste packaging procedures. Waste packaging procedures shall ensure that all pyrophoric radioactive materials are present only in small residual amounts (less than 1 weight percent) in payload containers.

CORROSIVES: Corrosives are prohibited in the payload container. Acids and bases that are potentially corrosive shall be neutralized and rendered noncorrosive prior to being a part of the waste. The physical form of the waste and the waste generating procedures ensure that the waste is in a nonreactive form.

CHEMICAL COMPATIBILITY: A chemical compatibility study has been performed on this content code, and all waste is chemically compatible for materials in greater than trace ( $>1 \%$ by weight) quantities. The chemicals found in this content code are identified in the attached list and are restricted to the allowable chemical lists determined by the methodology found in the RH-TRU 72-B Cask SAR.

ADDITIONAL CRITERIA: Each drum is fitted with a minimum of one filter vent with a minimum hydrogen diffusivity of 3.7E-06 mole/second/mole fraction. The steel liner is fitted with a filter with a minimum hydrogen diffusivity of 3.7E-06 mole/second/mole fraction.

MAXIMUM ALLOWABLE HYDROGEN GENERATION RATES - OPTION 1: The maximum allowable hydrogen generation rate limit is 3.8391E-08 moles per second per drum and 1.1517E-07 moles per second per RH-TRU waste canister with a fixed lid. The maximum allowable hydrogen generation rate limit is 3.2850E-08 moles per second per drum and 9.8550E-08 moles per second per RH-TRU waste canister with a removable lid. 
MAXIMUM ALLOWABLE DECAY HEAT LIMITS - OPTION 2: The maximum allowable decay heat limit is 0.6033 watts per drum and 1.8100 watts per RH-TRU waste canister with a fixed lid. The maximum allowable decay heat limit is 0.5170 watts per drum and 1.5500 watts per RH-TRU waste canister with a removable lid.

CORRELATION TABLE: N/A 


\title{
BATTELLE COLUMBUS LABORATORIES CONTENT CODE BC 314A CEMENTED INORGANIC PROCESS SOLIDS
}

\author{
MATERIALS AND CHEMICALS >1\%
}

DIATOMACEOUS EARTH (Floor Dry)

CEMENT SLUGS

\section{MATERIALS AND CHEMICALS $<1 \%$}

NITRIC ACID

WATER 
CONTENT CODE: BC 321A

CONTENT DESCRIPTION: Solid Organic Waste

GENERATING SITE: Battelle Columbus Laboratories (BCL)

STORAGE SITE: BCL

WASTE DESCRIPTION: This waste consists of a variety of combustible and noncombustible items.

GENERATING SOURCE(S): This waste is generated from activities supporting the decontamination and decommissioning of Building JN-1 under the Battelle Columbus Laboratories Decommissioning Project (BCLDP).

WASTE FORM: The waste may include combustible items such as cloth and paper products (e.g., from the cleanup of spills), rags, coveralls and booties, plastic, cardboard, rubber, wood, surgeons gloves, and Kimwipes. The waste may also include filter waste (e.g., dry box filters, HEPA filters, and filter cartridges); noncombustible Benelex and Plexiglas neutron shielding, blacktop, concrete, dirt, and sand; leaded gloves and aprons comprised of Hypalon rubber and lead oxide impregnated neoprene; and small amounts of metal waste. The waste may also include particulate and sludgetype organic process solids immobilized/solidified with Portland cement, vermiculite, Aqua-Set, or Petro-Set.

WASTE PACKAGING: The waste will be placed directly into a 55-gallon drum with no layers of confinement. The drum is lined with a steel liner. Three drums will then be placed into the RH-TRU waste canister.

METHOD(S) FOR ISOTOPIC DETERMINATION: The isotopic information required to demonstrate compliance with the limits on fissile content, decay heat, and curie content will be determined based on the waste generation source and configuration, which establish the initial radionuclide compositions based on location and initial use. A combination of assaying samples and modeling of the isotopic generation process, results in the establishment of a mixture that characterizes the waste in the content code and the majority of waste at the BCLDP. Using shipping package modeling, dose rate and weight measurement based on the mixture then allow the BCLDP 
to determine the isotopic inventory. As required, additional radioassays (e.g., confirming gamma spectroscopy) will be performed.

FREE LIQUIDS: Liquid waste, except for residual amounts in well-drained containers, is prohibited in the drums. The total volume of residual liquid in a payload container shall be less than 1 volume percent of the payload container. Waste packaging procedures ensure that free liquids are less than 1 volume percent of the payload container. Absorbents such as Radsorb or diatomaceous earth (e.g., Floor Dry) will be added to any waste matrix that has the potential to dewater after packaging.

EXPLOSIVES/COMPRESSED GASES: Explosives and compressed gases in the payload containers are prohibited by waste packaging procedures. If present, pressurized cans shall be punctured and emptied prior to packaging.

PYROPHORICS: Nonradioactive pyrophorics in the payload containers are prohibited by waste packaging procedures. Waste packaging procedures shall ensure that all pyrophoric radioactive materials are present only in small residual amounts (less than 1 weight percent) in payload containers.

CORROSIVES: Corrosives are prohibited in the payload container. Acids and bases that are potentially corrosive shall be neutralized and rendered noncorrosive prior to being a part of the waste. The physical form of the waste and the waste generating procedures ensure that the waste is in a nonreactive form.

CHEMICAL COMPATIBILITY: A chemical compatibility study has been performed on this content code, and all waste is chemically compatible for materials in greater than trace ( $>1 \%$ by weight) quantities. The chemicals found in this content code are identified in the attached list and are restricted to the allowable chemical lists determined by the methodology found in the RH-TRU 72-B Cask SAR.

ADDITIONAL CRITERIA: Each drum is fitted with a minimum of one filter vent with a minimum hydrogen diffusivity of 3.7E-06 mole/second/mole fraction. The steel liner is fitted with a filter with a minimum hydrogen diffusivity of 3.7E-06 mole/second/mole fraction. 
MAXIMUM ALLOWABLE HYDROGEN GENERATION RATES - OPTION 1: The maximum allowable hydrogen generation rate limit is 4.4110E-08 moles per second per drum and 1.3233E-07 moles per second per RH-TRU waste canister with a fixed lid. The maximum allowable hydrogen generation rate limit is 3.6380E-08 moles per second per drum and 1.0914E-07 moles per second per RH-TRU waste canister with a removable lid.

MAXIMUM ALLOWABLE DECAY HEAT LIMITS - OPTION 2: The maximum allowable decay heat limit is 0.1283 watts per drum and 0.3850 watts per RH-TRU waste canister with a fixed lid. The maximum allowable decay heat limit is 0.1127 watts per drum and 0.3380 watts per RH-TRU waste canister with a removable lid.

CORRELATION TABLE: N/A 


\title{
BATTELLE COLUMBUS LABORATORIES CONTENT CODE BC 321A SOLID ORGANIC WASTE
}

\author{
MATERIALS AND CHEMICALS $>1 \%$
}

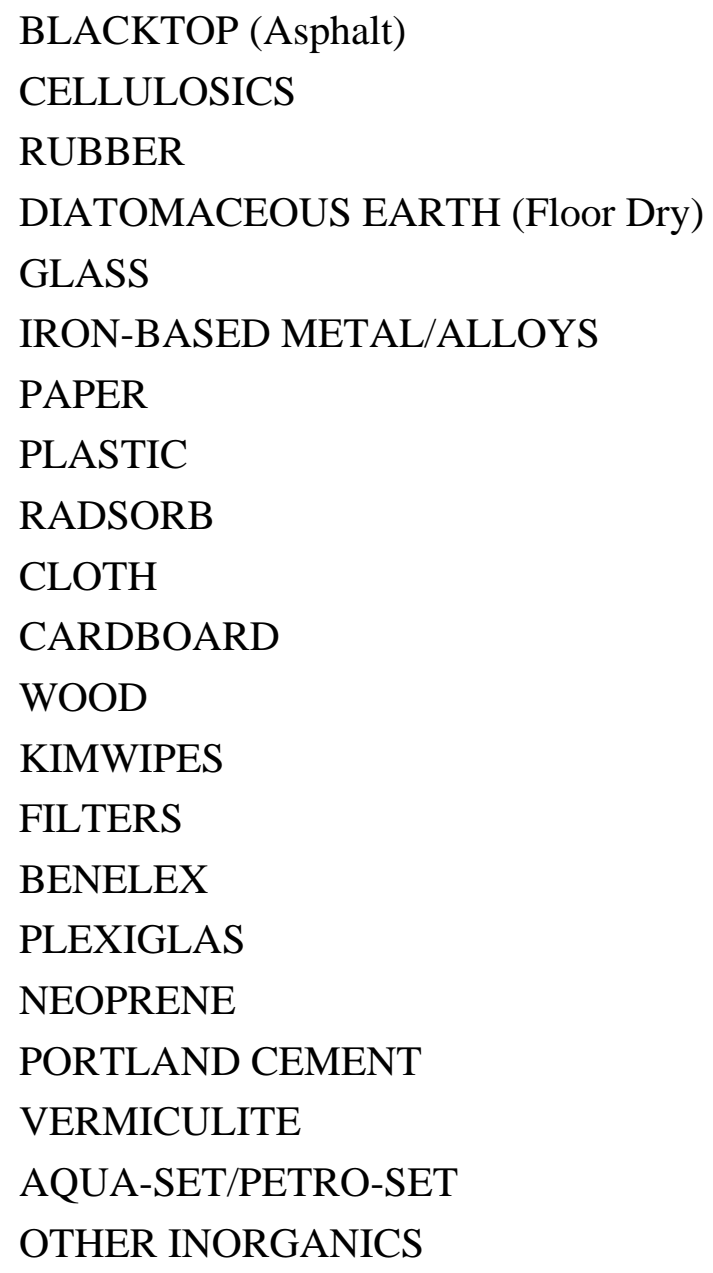

BLACKTOP (Asphalt)

CELLULOSICS

RUBBER

DIATOMACEOUS EARTH (Floor Dry)

GLASS

IRON-BASED METAL/ALLOYS

PAPER

PLASTIC

RADSORB

CLOTH

CARDBOARD

WOOD

KIMWIPES

FILTERS

BENELEX

PLEXIGLAS

NEOPRENE

PORTLAND CEMENT

VERMICULITE

AQUA-SET/PETRO-SET

OTHER INORGANICS

\section{MATERIALS AND CHEMICALS $<1 \%$}

METALS (including aluminum, lead, zirconium, stainless steel, and carbon steel) CONCRETE

SOIL 
CONTENT CODE: BC 321B

CONTENT DESCRIPTION: Solid Organic Waste

GENERATING SITE: Battelle Columbus Laboratories (BCL)

STORAGE SITE: BCL

WASTE DESCRIPTION: This waste consists of a variety of combustible and noncombustible items.

GENERATING SOURCE(S): This waste is generated during the change-out of resins in the Transfer/Storage Pool filtering system in Building JN-1 (Hot Cell Laboratory).

WASTE FORM: The waste may include filter waste (e.g., pool filters); nuclear grade resin, resin bags, paper, rubber gloves, Floor Dry bags, seals, hoses, valves, and clamps.

WASTE PACKAGING: The waste will be placed directly into a 55-gallon drum with no layers of confinement. The drum may be lined with a steel or polyethylene liner. Three drums will then be placed into the RH-TRU waste canister.

METHOD(S) FOR ISOTOPIC DETERMINATION: The isotopic information required to demonstrate compliance with the limits on fissile content, decay heat, and curie content will be determined based on the waste generation source and configuration, which establish the initial radionuclide compositions based on location and initial use. A combination of assaying samples and modeling of the isotopic generation process results in the establishment of a mixture that characterizes the waste in the content code. Using shipping package modeling, dose rate and weight measurements based on the mixture then allow the Battelle Columbus Laboratories Decommissioning Project (BCLDP) to determine the isotopic inventory. As required, additional radioassays (e.g., confirming gamma spectrometry) will be performed.

FREE LIQUIDS: Liquid waste, except for residual amounts in well-drained containers, is prohibited in the drums. The total volume of residual liquid in a payload container shall be less than 1 volume percent of the payload container. Waste packaging procedures ensure that free liquids are less than 1 volume percent of the payload container. Absorbents such as Radsorb or diatomaceous earth (e.g., Floor Dry) will be added to any waste matrix that has the potential to dewater after packaging. 
EXPLOSIVES/COMPRESSED GASES: Explosives and compressed gases in the payload containers are prohibited by waste packaging procedures. If present, pressurized cans shall be punctured and emptied prior to packaging.

PYROPHORICS: Nonradioactive pyrophorics in the payload containers are prohibited by waste packaging procedures. Waste packaging procedures shall ensure that all pyrophoric radioactive materials are present only in small residual amounts (less than 1 weight percent) in payload containers.

CORROSIVES: Corrosives are prohibited in the payload container. Acids and bases that are potentially corrosive shall be neutralized and rendered noncorrosive prior to being a part of the waste. The physical form of the waste and the waste generating procedures ensure that the waste is in a nonreactive form.

CHEMICAL COMPATIBILITY: A chemical compatibility study has been performed on this content code, and all waste is chemically compatible for materials in greater than trace ( $>1 \%$ by weight) quantities. The chemicals found in this content code are identified in the attached list and are restricted to the allowable chemical lists determined by the methodology found in the RH-TRU 72-B Cask SAR.

ADDITIONAL CRITERIA: Each drum is fitted with a minimum of one filter vent with a minimum hydrogen diffusivity of 3.7E-06 mole/second/mole fraction. The steel or polyethylene liner, if present, is either punctured or fitted with a filter with a minimum hydrogen diffusivity of 3.7E-06 mole/second/mole fraction.

MAXIMUM ALLOWABLE HYDROGEN GENERATION RATES - OPTION 1: The maximum allowable hydrogen generation rate limit is 4.4110E-08 moles per second per drum and 1.3233E-07 moles per second per RH-TRU waste canister with a fixed lid. The maximum allowable hydrogen generation rate limit is 3.6380E-08 moles per second per drum and 1.0914E-07 moles per second per RH-TRU waste canister with a removable lid.

MAXIMUM ALLOWABLE DECAY HEAT LIMITS - OPTION 2: The maximum allowable decay heat limit is 0.1557 watts per drum and 0.4670 watts per RH-TRU waste canister with a fixed lid. The maximum allowable decay heat limit is 0.1370 watts per drum and 0.4110 watts per RH-TRU waste canister with a removable lid.

CORRELATION TABLE: N/A 


\section{BATTELLE COLUMBUS LABORATORIES CONTENT CODE BC 321B SOLID ORGANIC WASTE}

\section{MATERIALS AND CHEMICALS $>1 \%$}

CELLULOSICS, PAPER, PLASTIC ( $\leq 12$ weight \%)

RUBBER

DIATOMACEOUS EARTH (Floor Dry)

ION EXCHANGE RESIN ( $\leq 80$ weight \%)

IRON-BASED METAL/ALLOYS

RADSORB

RESIN BAGS

FILTERS

OTHER INORGANICS

\section{MATERIALS AND CHEMICALS $<1 \%$}

METALS (including aluminum, lead, zirconium, stainless steel, and carbon steel) 
CONTENT CODE: BC 322A

CONTENT DESCRIPTION: Solid Inorganic Waste

GENERATING SITE: Battelle Columbus Laboratories (BCL)

STORAGE SITE: BCL

WASTE DESCRIPTION: This waste consists of a variety of glass and metal materials.

GENERATING SOURCE(S): This waste is generated during repackaging of the waste materials generated from research and development activities conducted in Building JN-1.

WASTE FORM: The waste consists primarily of glass and metal debris. Glass debris includes laboratory glassware, windows, leaded glass windows, and various glass apparatus. Metal items may include deteriorated berry cans, cable, wire, planchets, signs, valves, piping, strapping, tools, foils, sheeting, fixtures, equipment (e.g., pumps or motors that have had all oil or any other free liquids removed to $<1 \%$ ), hardware (e.g., nuts, bolts, brackets), specimen vials, fuel rod cladding, metallurgical mounts, and lead lined tubing. Metals of construction include stainless steel, aluminum, iron, copper, lead, beryllium, and zirconium.

WASTE PACKAGING: The waste will be placed directly into a 55-gallon drum with no layers of confinement. The drum is lined with a steel liner. Three drums will then be placed into the RH-TRU waste canister.

METHOD(S) FOR ISOTOPIC DETERMINATION: The isotopic information required to demonstrate compliance with the limits on fissile content, decay heat, and curie content will be determined based on the waste generation source and configuration, which establish the initial radionuclide compositions based on location and initial use. A combination of assaying samples and modeling of the isotopic generation process used in the establishment of a mixture that characterizes the waste in the content code and the majority of waste at the Battelle Columbus Laboratories Decommissioning Project (BCLDP). Using shipping package modeling, dose rate and weight measurements based on the mixture then allow the BCLDP to determine the isotopic inventory. As required, additional radioassays (e.g., confirming gamma spectroscopy) will be performed. 
FREE LIQUIDS: Liquid waste, except for residual amounts in well-drained containers, is prohibited in the drums. The total volume of residual liquid in a payload container shall be less than 1 volume percent of the payload container. Waste packaging procedures ensure that free liquids are less than 1 volume percent of the payload container. Absorbents such as diatomaceous earth (e.g., Floor Dry) will be added to any waste matrix that has the potential to dewater after packaging.

EXPLOSIVES/COMPRESSED GASES: Explosives and compressed gases in the payload containers are prohibited by waste packaging procedures. If present, pressurized cans shall be punctured and emptied prior to packaging.

PYROPHORICS: Nonradioactive pyrophorics in the payload containers are prohibited by waste packaging procedures. Waste packaging procedures shall ensure that all pyrophoric radioactive materials are present only in small residual amounts (less than 1 weight percent) in payload containers.

CORROSIVES: Corrosives are prohibited in the payload container. Acids and bases that are potentially corrosive shall be neutralized and rendered noncorrosive prior to being a part of the waste. The physical form of the waste and the waste generating procedures ensure that the waste is in a nonreactive form.

CHEMICAL COMPATIBILITY: A chemical compatibility study has been performed on this content code, and all waste is chemically compatible for materials in greater than trace ( $>1 \%$ by weight) quantities. The chemicals found in this content code are identified in the attached list and are restricted to the allowable chemical lists determined by the methodology found in the RH-TRU 72-B Cask SAR.

ADDITIONAL CRITERIA: Each drum is fitted with a minimum of one filter vent with a minimum hydrogen diffusivity of 3.7E-06 mole/second/mole fraction. The steel liner is fitted with a filter with a minimum hydrogen diffusivity of 3.7E-06 mole/second/mole fraction.

MAXIMUM ALLOWABLE HYDROGEN GENERATION RATES - OPTION 1: The maximum allowable hydrogen generation rate limit is 3.8391E-8 moles per second per drum and 1.1517E-7 moles per second per RH-TRU waste canister with a fixed lid. The maximum allowable hydrogen generation rate limit is 3.2850E-08 moles per second per drum and 9.8550E-08 moles per second per RH-TRU waste canister with a removable lid.

. $13 q$

MAXIMUM ALLOWABLE DECAY HEAT LIMITS - OPTION 2: The maximum allowable decay heat limit is 16.6700 watts per drum and 50.0000 watts per RH-TRU waste canister with a 
fixed lid. The maximum allowable decay heat limit is 15.5000 watts per drum and 46.5000 watts per RH-TRU waste canister with a removable lid.

CORRELATION TABLE: N/A 


\section{BATTELLE COLUMBUS LABORATORIES CONTENT CODE BC 322A SOLID INORGANIC WASTE}

\section{MATERIALS AND CHEMICALS >1\%}

CEMENT

DIATOMACEOUS EARTH (Floor Dry)

GLASS

METALS (including stainless steel, aluminum, iron, copper, lead, beryllium, and zirconium) IRON-BASED METAL/ALLOYS

OTHER INORGANICS

$$
\text { MATERIALS AND CHEMICALS }<1 \%
$$

CARBON TETRACHLORIDE

1,1,1-TRICHLOROETHANE

TRICHLOROETHYLENE 
CONTENT CODE: ET 325A

CONTENT DESCRIPTION: Solid Organic and Inorganic Waste

GENERATING SITE: Energy Technology Engineering Center (ETEC)

STORAGE SITE: ETEC

WASTE DESCRIPTION: This waste consists of Hot Laboratory debris including paper, plastic, metal and glass.

GENERATING SOURCE(S): Solid organic and inorganic debris waste was generated during decontamination and decommissioning (D\&D) operations at the former ETEC-associated Hot Laboratory.

WASTE FORM: The debris waste consists of miscellaneous waste materials removed from the facility during $\mathrm{D} \& \mathrm{D}$, including a small capped pipe that contains unirradiated plutonium oxide/ uranium oxide pieces from ETEC’s former Nuclear Materials Development Facility, canisters of paint chips surrounded by lead shielding, and a lead brick.

WASTE PACKAGING: The waste is in two plastic bag layers, which are folded and taped, in a 55-gallon drum. Three 55-gallon drums are then placed into the RH-TRU waste canister.

METHOD(S) FOR ISOTOPIC DETERMINATION: The required isotopic information to demonstrate compliance with the limits on fissile content, decay heat, and curie content will be determined based on acceptable knowledge, the radioassay of samples, or on total drum activity measurements, taken on the product material.

FREE LIQUIDS: Liquid waste, except for residual amounts in well-drained containers, is prohibited in the drums. The total volume of residual liquid in a payload container shall be less than 1 volume percent of the payload container. Waste packaging procedures ensure that free liquids are less than 1 volume percent of the payload container.

EXPLOSIVES/COMPRESSED GASES: Explosives and compressed gases in the payload containers are prohibited by waste packaging procedures. If present, pressurized cans shall be punctured and emptied prior to packaging. 
PYROPHORICS: Nonradioactive pyrophorics in the payload containers are prohibited by waste packaging procedures. Process knowledge indicates that no non-radioactive pyrophoric material was generated in association with the waste. Waste packaging procedures shall ensure that all radioactive pyrophoric materials are present only in small residual amounts (less than 1 weight percent) in payload containers.

CORROSIVES: Corrosives are prohibited in the payload container. Acids and bases that are potentially corrosive shall be neutralized or rendered noncorrosive prior to being a part of the waste. The physical form of the waste and the waste generating procedures ensure that the waste is in a nonreactive form.

CHEMICAL COMPATIBILITY: A chemical compatibility study has been performed on this content code, and all waste is chemically compatible for materials in greater than trace ( $>1 \%$ by weight) quantities. The chemicals found in this content code are identified in the attached list and are restricted to the allowable chemical lists determined by the methodology found in the RH-TRU 72-B Cask SAR.

ADDITIONAL CRITERIA: Each drum is fitted with a minimum of one filter vent. Drum filters have a minimum hydrogen diffusivity of 3.7E-06 mole/second/mole fraction. If present, rigid liners in 55 -gallon drums shall be punctured with a $\geq 0.3$-inch diameter hole for gas release.

MAXIMUM ALLOWABLE HYDROGEN GENERATION RATES - OPTION 1: The maximum allowable hydrogen generation rate limit is 3.2270E-8 moles per second per drum and 9.6810E-8 moles per second per RH-TRU waste canister with a fixed lid. The maximum allowable hydrogen generation rate limit is 2.8160E-08 moles per second per drum and $8.4480 \mathrm{E}-08$ moles per second per RH-TRU waste canister with a removable lid.

MAXIMUM ALLOWABLE DECAY HEAT LIMITS - OPTION 2: The maximum allowable decay heat limit is 0.1047 watts per drum and 0.3140 watts per RH-TRU waste canister with a fixed lid. The maximum allowable decay heat limit is 0.0963 watts per drum and 0.2890 watts per RH-TRU waste canister with a removable lid.

CORRELATION TABLE: This waste has previously been identified as the following IDCs:

$\underline{\text { IDC }}$ DESCRIPTION GENERATING SITE

253 Solid Inorganic and Organic Waste ETEC 


\title{
ENERGY TECHNOLOGY ENGINEERING CENTER (ETEC) CONTENT CODE ET 325A \\ IDC 253 \\ SOLID ORGANIC AND INORGANIC WASTE
}

\author{
MATERIALS AND CHEMICALS > 1\%
}

\section{CLOTH}

CONCRETE PARTICULATE

FILTERS

GLASS

METALS(e.g., aluminum, titanium, iron, copper, lead, tungsten, brass, steel and stainless steel, tantalum)

PuO/UO PIECES (unirradiated; Pu content 0.7 g)

PAINT CHIPS (strippable paint)

PLASTIC

PAPER

VERMICULITE

\section{MATERIALS AND CHEMICALS $<1 \%$}

\section{CLEANERS}

OILS

SOLVENTS

SEALANT MATERIAL 
CONTENT CODE: ET 326A

CONTENT DESCRIPTION: Solidified Organic Process Waste

GENERATING SITE: Energy Technology Engineering Center (ETEC)

STORAGE SITE: ETEC

WASTE DESCRIPTION: This waste consists of drain line residue, including organic sludges and sludge-like materials, steel and concrete components.

GENERATING SOURCE(S): This waste is primarily solidified sludge that was removed from the former ETEC-associated Hot Laboratory drain line system and drain tank during decontamination and decommissioning operations. The waste includes fines that are the result of cutting and grinding operations.

WASTE FORM: The waste consists of materials that were washed out of operational hot cells. The primary constituents are steel and fuel element fines (including TRU, fission products, and activated cladding residue) from declad grinding and cutting operations, sludge wastes, steel and concrete debris, sand, dirt, grinding materials, and concrete dust/particulate. The sludge wastes are, in part, the result of solidification or liquid absorption procedures using diatomaceous earth, fly ash, cement, or concrete.

WASTE PACKAGING: The waste is packaged directly into 55-gallon drums or will be packaged in closed 1-gallon paint cans, larger vented metal cans, or punctured 5-gallon buckets and then will be placed into a 55-gallon drum. The 1-gallon paint cans or 5-gallon buckets may also be overpacked in the larger vented metal cans and then placed into a 55-gallon drum. The drums may be lined with thick annular concrete shields (between the waste containers and the drum walls). Bottom and top concrete shields plus thick steel lids may also be used inside the drums. Three 55gallon drums are then placed into the RH-TRU waste canister.

METHOD(S) FOR ISOTOPIC DETERMINATION: The required isotopic information to demonstrate compliance with the limits on fissile content, decay heat, and curie content will be determined based on acceptable knowledge, the radioassay of samples, and on total drum activity measurements taken on the product material during the processing at the site. 
FREE LIQUIDS: Liquid waste, except for residual amounts in well-drained containers, is prohibited in the drums. The total volume of residual liquid in a payload container shall be less than 1 volume percent of the payload container. Site procedures for liquid absorption and solidification ensure that free liquids are less than 1 volume percent of the payload container.

EXPLOSIVES/COMPRESSED GASES: Explosives and compressed gases in the payload containers are prohibited by waste packaging procedures. If present, pressurized cans shall be punctured and emptied prior to packaging.

PYROPHORICS: Nonradioactive pyrophorics in the payload containers are prohibited by waste packaging procedures. Process knowledge indicates that no non-radioactive pyrophoric material was generated in association with waste. Waste packaging procedures shall ensure that all radioactive pyrophoric materials are present only in small residual amounts (less than 1 weight percent) in payload containers.

CORROSIVES: Corrosives are prohibited in the payload container. Acids and bases that are potentially corrosive shall be neutralized or rendered noncorrosive prior to being a part of the waste. The physical form of the waste and the waste generating procedures ensure that the waste is in a nonreactive form.

CHEMICAL COMPATIBILITY: A chemical compatibility study has been performed on this content code, and all waste is chemically compatible for materials in greater than trace ( $>1 \%$ by weight) quantities. The chemicals found in this content code are identified in the attached list and are restricted to the allowable chemical lists determined by the methodology found in the RH-TRU 72-B Cask SAR.

ADDITIONAL CRITERIA: Each drum is fitted with a minimum of one filter vent. Drum filters have a minimum hydrogen diffusivity of 3.7E-06 mole/second/mole fraction. Inner containers greater than 4 liters in volume are punctured or vented to allow free gas release.

MAXIMUM ALLOWABLE HYDROGEN GENERATION RATES - OPTION 1: The maximum allowable hydrogen generation rate limit is 4.8140E-8 moles per second per drum and 1.4442E-7 moles per second per RH-TRU waste canister with a fixed lid. The maximum allowable hydrogen generation rate limit is 3.9510E-08 moles per second per drum and 1.1853E-07 moles per second per RH-TRU waste canister with a removable lid. 
MAXIMUM ALLOWABLE DECAY HEAT LIMITS - OPTION 2: The maximum allowable decay heat limit is 0.2107 watts per drum and 0.6320 watts per RH-TRU waste canister with a fixed lid. The maximum allowable decay heat limit is 0.1870 watts per drum and 0.5600 watts per RH-TRU waste canister with a removable lid.

CORRELATION TABLE: N/A 
CONTENT CODE: ET 326B

CONTENT DESCRIPTION: Solidified Organic Process Waste

GENERATING SITE: Energy Technology Engineering Center (ETEC)

STORAGE SITE: ETEC

WASTE DESCRIPTION: This waste consists of drain line residue, including organic sludges and sludge-like materials, steel and concrete components.

GENERATING SOURCE(S): This waste is primarily solidified sludge that was removed from the former ETEC-associated Hot Laboratory drainline system and drain tank during decontamination and decommissioning operations. The waste includes fines that are the result of cutting and grinding operations.

WASTE FORM: The waste consists of materials that were washed out of operational hot cells. The primary constituents are steel and fuel element fines (including TRU, fission products, and activated cladding residue) from declad grinding and cutting operations, sludge wastes, steel and concrete debris, sand, dirt, grinding materials, and concrete dust/particulate. The sludge wastes are in part the result of solidification or liquid absorption procedures using diatomaceous earth, fly ash, cement, or concrete.

WASTE PACKAGING: The waste is packaged directly into an RH-TRU waste canister, or will be packaged in closed 1-gallon paint cans, larger vented metal cans, or punctured 5-gallon buckets and then placed into an RH-TRU waste canister. The 1-gallon paint cans or 5-gallon buckets may also be overpacked in the larger vented metal cans and then placed into the RH-TRU waste canister.

METHOD(S) FOR ISOTOPIC DETERMINATION: The required isotopic information to demonstrate compliance with the limits on fissile content, decay heat, and curie content will be determined based on acceptable knowledge, the radioassay of samples, and on total drum activity measurements taken on the product material during the processing at the site. 
FREE LIQUIDS: Liquid waste, except for residual amounts in well-drained containers, is prohibited in the drums. The total volume of residual liquid in a payload container shall be less than 1 volume percent of the payload container. Site procedures for liquid absorption and solidification ensure that free liquids are less than 1 volume percent of the payload container.

EXPLOSIVES/COMPRESSED GASES: Explosives and compressed gases in the payload containers are prohibited by waste packaging procedures. If present, pressurized cans shall be punctured and emptied prior to packaging.

PYROPHORICS: Nonradioactive pyrophorics in the payload containers are prohibited by waste packaging procedures. Process knowledge indicates that no non-radioactive pyrophoric material was generated in association with the waste. Waste packaging procedures shall ensure that all radioactive pyrophoric materials are present only in small residual amounts (less than 1 weight percent) in payload containers.

CORROSIVES: Corrosives are prohibited in the payload container. Acids and bases that are potentially corrosive shall be neutralized or rendered noncorrosive prior to being a part of the waste. The physical form of the waste and the waste generating procedures ensure that the waste is in a nonreactive form.

CHEMICAL COMPATIBILITY: A chemical compatibility study has been performed on this content code, and all waste is chemically compatible for materials in greater than trace ( $>1 \%$ by weight) quantities. The chemicals found in this content code are identified in the attached list and are restricted to the allowable chemical lists determined by the methodology found in the RH-TRU 72-B Cask SAR.

ADDITIONAL CRITERIA: Each RH-TRU waste canister is fitted with a minimum of one filter vent. Waste canister filters will have with a minimum hydrogen diffusivity as specified in Appendix 1.3 .5 of the 72-B Cask SAR. Inner containers greater than 4 liters in volume are punctured or vented to allow free gas release.

MAXIMUM ALLOWABLE HYDROGEN GENERATION RATES - OPTION 1: The maximum allowable hydrogen generation rate limit is $1.8449 \mathrm{E}-7$ moles per second per RH-TRU waste canister with a fixed lid. The maximum allowable hydrogen generation rate limit is 1.3677E-07 moles per second per RH-TRU waste canister with a removable lid. 
MAXIMUM ALLOWABLE DECAY HEAT LIMITS - OPTION 2: The maximum allowable decay heat limit is 0.6110 watts per RH-TRU waste canister with a fixed lid. The maximum allowable decay heat limit is 0.5290 watts per RH-TRU waste canister with a removable lid.

CORRELATION TABLE: N/A 


\title{
ENERGY TECHNOLOGY ENGINEERING CENTER (ETEC) CONTENT CODE ET 326 SOLIDIFIED ORGANIC PROCESS WASTE
}

\author{
MATERIALS AND CHEMICALS $>1 \%$
}

\begin{abstract}
ABSORBENTS (diatomaceous earth, vermiculite, fly ash, cement, concrete)
CONCRETE AND CONCRETE DUST/PARTICULATE

DIRT

GLASS

GRINDING MATERIALS (carborundum, other carbides) IRON OXIDES

METALS (including carbon steel [containers, weir boxes, grindings and shavings], aluminum, chromium, titanium, zinc, beryllium, magnesium, calcium, iron, nickel, copper, mercury, tungsten, zirconium, cadmium, brass stainless steel [primarily grindings and shavings], molybdenum, lead)

PAINT CHIPS

PLASTIC

SAND (silica and alumina based)
\end{abstract}

\section{MATERIALS AND CHEMICALS $<1 \%$}

\section{ACETONE}

ALCOHOL

ALCONOX

BIG ORANGE CLEANER

CALCIUM CARBONATE

CAUSTIC CLEANERS: Oakite, MX-12, Big K (potassium hydroxide)

DOWANOL

ELECTROPOLISH (phosphoric and sulfuric acid)

FOGPROOF

FREON

GRAPHITE

HYDROFLUORIC, NITRIC, HYDROCHLORIC, CITRIC, PERCHLORIC/OXALIC ACID 


\title{
ENERGY TECHNOLOGY ENGINEERING CENTER (ETEC) CONTENT CODE ET 326 \\ (Continued) \\ SOLIDIFIED ORGANIC PROCESS WASTE
}

MATERIALS AND CHEMICALS $<1 \%$

\author{
KEROSENE \\ OIL, MINERAL OIL, HYDRAULIC OIL, CUTTING OIL, SPRAY LUBRICANTS \\ PETROSET, AQUASET, EARTH-TITE \\ RADIAC WASH \\ SODIUM OXIDE \\ TRICHLOROETHYLENE \\ TURCO PRODUCTS (alkaline cleaners), DEFOAMING AGENTS \\ WINDEX \\ ZEP SPRAY
}

